\title{
EXTRADIÇÃO E JUDICIALIZAÇÃO DA POLÍTICA: O CASO SEM PRECEDENTES DE CESARE BATTISTI
}

EXTRADICIÓN Y JUDICIALIZACIÓN DE LA POLÍTICA: EL CASO SIN PRECEDENTES DE CESARE BATTISTI

EXTRADITION AND THE JUDICIALIZATION OF POLITICS: THE UMPRECEDENTED CASE OF CESARE BATTISTI

\section{EXTRADITION ET JUDICIARISATION DE LA POLITIQUE : LE CAS SANS PRÉCÉCENTS DE CESARE BATTISTI}

\section{引渡和政治问题的法制化一没有先例的切萨里·巴蒂斯提引渡案。}

\author{
Alexandre Pereira da Silva ${ }^{1}$ \\ Mariana Yante Barrêto Pereira ${ }^{2}$
}

\section{RESUMO}

O presente trabalho procura suscitar reflexões sobre a judicialização da política no processo de extradição. Essa análise se dará por meio do exame da mudança de atuação do STF, em especial na Extradição 1.085, também conhecida como "caso Cesare Battisti". Trata-se de um caso sem precedentes no Supremo Tribunal Federal, seja politicamente, pelo debate acalorado entre os Ministros, seja juridicamente, pelo surgimento de uma série de questões que nunca haviam sido enfrentadas e que, em certa medida, transcendem os aspectos jurídicos aos quais era limitada a atuação da Corte

\footnotetext{
${ }^{1}$ Professor Adjunto de Direito Internacional Público da Faculdade de Direito do Recife/Universidade Federal de Pernambuco (FDR/UFPE). Pós-doutor em Direito pela Schulich School of Law, Dalhousie, University, Halifax, Canadá. E-mail: Ipsilva.alexandre@gmail.com

${ }^{2}$ Bacharel em Direito pela Universidade Federal de Pernambuco. Mestre em Ciência Política e Doutoranda em Direito pela mesma instituição. Pesquisadora do Núcleo de Pesquisas Regionais e do Desenvolvimento da Universidade Federal de Pernambuco (D\&R/UFPE). E-mail: marianayante@gmail.com
} 
Suprema. Dessa forma, o artigo tem por objetivos examinar o caso Battisti e a relativização da autonomia do Executivo em extradição, trazendo questões sobre as consequências advindas do julgamento pelo Tribunal, e, consequentemente, sobre o limite da eficácia das decisões administrativas.

Palavras-chave: Judicialização da política; Supremo Tribunal Federal; Extradição.

\section{RESUMEN}

El presente trabajo busca contribuir a la reflexión sobre la judicialización de la política en el proceso de extradición. El análisis se basa sobre el examen del cambio en la actuación del Supremo Tribunal Federal (STF), en particular en la Extradición 1.085, también conocida como "caso Cesare Battisti". Se trata de un caso sin precedentes para el STF, tanto a nivel político, con un debate apasionado entre los Ministros, como a nivel jurídico, con la aparición de una serie de cuestiones que nunca habían sido contempladas y que, de alguna manera, transcienden los aspectos jurídicos a los cuales se limitaba la actuación de la Corte Suprema. En este sentido, el objetivo del artículo es de analizar el caso Battisti y la relativización de la autonomía del Ejecutivo en la extradición, que genera dudas respecto a las consecuencias del juicio adoptado por el Tribunal, y consecuentemente, a la eficacia de las decisiones administrativas.

Palabras clave: Judicialización de la política, Supremo Tribunal Federal, Extradición.

\section{ABSTRACT}

This work aims to offer reflections on the judicialization of politics in the extradition procedure. The analysis will proceed by means of an examination of the shift in the Supreme Federal Court's interventions, particularly in Extradition 1,085, also known as the "Cesare Battisti case". This case was wholly unprecedented for the Supreme Federal Court, both politically, due to the heated debate between ministers, and legally, due to the emergence of a series of issues which had never been tackled before, and which somewhat transcend the juridical features limiting the Supreme Court's scope. The article thus seeks to examine the Battisti case and the qualifications applying to executive autonomy in matters of extradition, considering issues surrounding the consequences arising from the tribunal's ruling and therefore the limits of the effectiveness of administrative decisions. 
Key words: Judicialization of politics, Supreme Federal Court, Extradition.

\section{RÉSUMÉ}

Le présent article cherche à susciter une réflexion sur la judiciarisation de la politique dans le processus d'extradition. Cette analyse se fera grâce à l'examen des changements intervenus dans l'action du STF, principalement dans le cadre de l'Extradition 1.085, également connue comme le « cas Cesare Battisti ». II s'agit d'un cas sans précédents au Tribunal suprême fédéral, aussi bien politiquement, en fonction de l'intense débat entre les juges, que juridiquement, en raison de l'apparition d'une série de questions jamais traitées auparavant et qui, dans une certaine mesure, transcendent les aspects juridiques auxquels se limitait l'action de la Cour suprême. Cet article a donc pour objectif d'examiner le cas Battisti et la relativisation de l'autonomie de l'Exécutif quant aux extraditions, posant ainsi la question des conséquences de ce jugement du Tribunal et, par conséquent, des limites de l'efficacité des décisions administratives.

Mots-clés : Judiciarisation de la politique, Tribunal suprême fédéral, Extradition.

\section{摘要 :}

本论文旨在发起在引渡过程中政治的法制化的现象的反思。通过分析巴西联邦最高法院在此 案中的行为变化, 特别是1085号引渡案, 也就是广为人知的切萨里·巴蒂斯提(Cesare Battisti)引渡案, 作者对该案引起的政治争议进行反思。这是一个在联邦最高法院里史无前 例的案件, 无论在政治争论方面引起的部长们之间的强烈不同意见, 和在法制方面引起的前 所没有的问题。该案超出了联邦最高法院的范围。本文检查引渡案过程中矢于行政机矢的权 力问题，法院裁判结果对行政自主权的影响，以及行政管理机矢的决断的效力问题。

关键词: 政治法制化; 联邦最高法院；引渡

\section{Introdução}

O processo de extradição do italiano Cesare Battisti - acusado do envolvimento na morte de quatro pessoas na época em que era membro do movimento PAC 
(Proletários Armados pelo Comunismo), grupo de esquerda que operou na Itália na década de 1970 - foi solicitado pela Itália ao Brasil e é um caso sem precedentes na história do Supremo Tribunal Federal (STF), órgão máximo do Judiciário brasileiro.

Sem precedentes pelo debate político acalorado, e também juridicamente por uma série de questões que nunca haviam sido enfrentadas nesse tipo de processo, como, por exemplo, se o ato do Ministro da Justiça de concessão de asilo é um ato administrativo vinculado ou discricionário e se a decisão de concessão de extradição é obrigatória ou não para o Presidente da República.

Mais do que isso, o processo de extradição n. 1.085 - o caso Battisti demonstrou de maneira inegável a atuação política do STF, em um movimento conhecido como "judicialização da política", que se insere também no processo de extradição.

\section{Judicialização da política e extradição}

Do ponto de vista funcional, a independência do Judiciário relaciona-se ao crescimento de sua autonomia a partir do alargamento dos direitos fundamentais e da instituição da revisão constitucional, o que vem fortalecendo paralelamente o fenômeno da judicialização da política.

A revisão constitucional, mesmo em sistemas parlamentares, vem sendo adotada pelos países diante da sua relevância como mecanismo de efetivação constitucional, embora tenha mais impactos sobre as políticas públicas quando suas características procedimentais são de descentralização e envolvem mais órgãos que em países que possuam exclusivamente controle concentrado de constitucionalidade em um único tribunal constitucional.

Segundo Hirschl, o fortalecimento da judicialização da mega-política é explicado principalmente pelas disputas de poder político e emergência de uma nova configuração de poder, cuja ameaça aos interesses das elites e de outros agentes influentes leva à busca pela tutela constitucional e pela proteção das cortes. ${ }^{3}$

\footnotetext{
${ }^{3}$ Hirschl, Ran (2008). "The Judicialization of Mega-Politics and the Rise of Political Courts". In The Annual Review of Political Science, v. 11, n. 1, p. 108. Embora não seja um conceito delimitado em seu trabalho, Hirschl abrange na terminologia "judicialização da mega-política" o aumento da abrangência e relevância das questões de direito ou cooperação transnacional submetidas às cortes a partir do que entende por "terceiro nível de judicialização", passando a incluir, entre outros temas, controvérsias em processos eleitorais; política fiscal, comércio exterior e segurança nacional e corroboração de mudanças de regime.
} 
No caso brasileiro, o crescente movimento de ativismo judicial tem recebido peculiar apoio da mídia e mesmo da comunidade acadêmica jurídica do país, por um lado com a "espetacularização" dos julgamentos e casos paradigmáticos levados ao Supremo Tribunal Federal, e, por outro, com o atrelamento da judicialização da política a concepções progressistas e inovadoras sobre o delineamento de políticas públicas:

No Brasil, é muito comum traçar-se um paralelo entre a defesa do ativismo judicial e posições sociais progressistas. Talvez isso se deva ao fato de que, na nossa história, o Judiciário brasileiro tem pecado muito mais por omissão, acumpliciando-se diante dos desmandos dos poderes político e econômico, do que por excesso de ativismo. Neste quadro, quem ousa questionar possíveis exageros na judicialização da política e da vida social no Brasil de hoje é logo tachado de conservador. Porém, o paralelismo em questão não existe. ${ }^{4}$

No deslinde do caso Battisti, o não acolhimento do posicionamento do STF pelo Chefe do Executivo brasileiro foi criticamente noticiado pela grande parte da imprensa. Um exemplo foi a divulgação da informação da moção votada pelo Parlamento Europeu, que em 19 de janeiro de 2012, requerera que o Brasil revisse a decisão de não extraditar o italiano. ${ }^{5}$

No caso Battisti, o elemento de discricionariedade dos atos da Administração termo jurídico que evoca o livre arbítrio dos administradores para formular seu juízo de conveniência e oportunidade sobre a realização de seus atos - e seu conteúdo foram a base para a atuação da Corte Suprema no processo de extradição.

No Brasil, a inclusão do Judiciário no processo extradicional cindiu-o em uma apreciação administrativa e uma jurisdicional. Enquanto a cognição do STF é limitada, ao Executivo cabe a análise do pressuposto negativo para a concessão da extradição - a não configuração de crime político ou de opinião, cuja existência autoriza (ou obriga) o país a conceder asilo ao extraditando, nos termos do art. 5ํㅡ, LII, da Constituição Federal.

\footnotetext{
${ }^{4}$ Sarmento, Marcelo (2009). "Neoconstitucionalismo no Brasil: riscos e possibilidades". In: Novelino, Marcelo (Org.) (2009). Leituras complementares de Direito Constitucional. Teoria da Constituição, Salvador: Jus Podivm, p. 40.

${ }^{5} \mathrm{Na}$ ocasião, a Folha de São Paulo divulgou a notícia em seu sítio eletrônico, com a seguinte manchete "Os membros do Parlamento Europeu pediram nesta quinta-feira [19/01] que o Brasil reveja a decisão de não extraditar o ativista italiano Cesare Battisti". Outros veículos, como "O Estadão" e o "Portal Terra" (que vincula informações da agência internacional Agence France-Presse ou AFP), também noticiaram que a decisão se deu por 83 votos favoráveis e apenas duas abstenções, omitindo, todavia, que houve apenas o comparecimento de $11,7 \%$ dos 736 membros do órgão supranacional, dos quais 77 eram italianos e 9 de outros países.
} 
Trata-se não propriamente de um ato administrativo, mas de governo ou político, pois praticado pelo administrador no exercício da atividade política, com margem de discrição e com fundamento na Carta Magna. ${ }^{6}$

Com o crescimento no país dos debates sobre accountability e mecanismos de controle democrático dos poderes estatais - traduzidos no Direito pela incorporação das normas jurídicas principiológicas - a doutrina passou a admitir o controle de mérito sobre tais atos, desde que comprometessem a legalidade ou ferissem os princípios da razoabilidade e proporcionalidade. ${ }^{7}$

No caso em análise, a indefinição desses conceitos e a existência de uma legislação superficial sobre extradição e asilo político, a qual, em adição, foi poucas vezes aplicada a fundo, conduziram às muitas dúvidas sobre a extensão da ingerência do Judiciário sobre tais atos.

Aliado a isso, a postura intervencionista do Supremo Tribunal Federal em questões políticas e a tendência de valorização do ativismo judicial contribuíram para que a extradição de Cesare Battisti se tornasse um caso emblemático para análise desse quadro jurídico-político.

\section{Síntese do caso}

Nascido em dezembro de 1954, Cesare Battisti foi membro do movimento conhecido como PAC (Proletários Armados pelo Comunismo), grupo de esquerda que operou na Itália na década de 1970.

Segundo o próprio Battisti em entrevista ao semanário IstoÉ, ele fez parte da organização durante dois anos entre 1976 e 1978, saindo em maio deste ano depois da morte do ex-primeiro-Ministro Aldo Moro pelas Brigadas Vermelhas. Battisti diz também que nunca foi militante militar em nenhuma organização e nega veementemente qualquer envolvimento nos crimes objeto do pedido extradicional. ${ }^{8}$

O objeto da Extradição 1.085 consiste na condenação definitiva de Cesare Battisti, por decisão da Corte de Apelações de Milão, à pena de prisão perpétua, com isolamento diurno inicial por seis meses, pela prática de quatro crimes: i) homicídio

\footnotetext{
${ }^{6}$ Mello, Celso Antônio Bandeira de (2009). Curso de Direito Administrativo. 26. ed., São Paulo: Malheiro, p. 378-379.

${ }^{7}$ Dworkin, Ronald (2007). Levando os direitos a sério. 2 ed., São Paulo: Martins Fontes.

${ }^{8}$ Villaméa, Luiza (2009). "Cesare Battisti: 'Por que tudo isso comigo?'”. In Isto é, São Paulo, v. 2047,4 fev. 
premeditado do agente penitenciário Antonio Santoro, fato que aconteceu em Udine em 6 de junho de 1977; ii) homicídio do joalheiro Pierluigi Torregiani, ocorrido em Milão em 16 de fevereiro de 1979; iii) homicídio premeditado do açogueiro Lino Sabbadin, ocorrido em Mestre em 16 de fevereiro de 1979; e, iv) homicídio premeditado do agente de polícia Andrea Campagna, ocorrido em Milão, em 19 de abril de 1979.

Battisti chegou a ser preso em junho de 1979, sendo condenado a doze anos de prisão. No entanto, em outubro de 1981, conseguiu fugir do presídio de Frosinone. Evadindo-se primeiro para a França, onde ficou por um ano, posteriormente para o México. Depois de quase sete anos no México, voltou para a França em 1990, onde ficou inicialmente preso por quatro meses, em razão de pedido de extradição da justiça italiana. No entanto, a extradição foi negada pela Câmara de Acusação de Paris. Libertado, seguiu vivendo na França ao abrigo da Doutrina Mitterand, que aceitava a presença dos envolvidos em atos de violência, desde que fizessem renúncia formal à luta armada.

Posteriormente, a Doutrina Mitterand foi revogada, e com isso, a extradição requerida pela Itália tornou-se novamente uma realidade factível. Assim, em 2004, 0 Conselho de Estado da França analisou novo pedido e autorizou que Battisti fosse extraditado. No entanto, antes que o decreto fosse assinado, Battisti fugiu para o Brasil, chegando em Fortaleza em setembro de 2004.

No Brasil, permaneceu escondido durante dois anos e meio, até que, em março de 2007, a Itália solicitou pedido de extradição. Em novembro de 2007, o Ministro Celso de Mello, por razões de foro íntimo, deu-se por suspeito. Depois de redistribuído o processo, a relatoria ficou com o Ministro Cezar Peluso.

\section{Pedido de refúgio ao CONARE: decisão apertada contra a concessão}

Já preso, Cesare Battisti solicitou perante o Comitê Nacional para os Refugiados (CONARE) que fosse reconhecida sua condição de perseguido político, com base no art. $1^{\circ}$, I, da Lei n. 9.474/979.

Com o pedido de refúgio sendo examinado pelo CONARE, o processo de extradição fica suspenso, nos termo do art. 34 desse mesmo diploma legal.

\footnotetext{
9 "Será reconhecido como refugiado todo indivíduo que: I - devido a fundados temores de perseguição por motivos de raça, religião, nacionalidade, grupo social ou opiniões políticas encontre-se fora de seu país de nacionalidade e não possa ou não queira acolher-se à proteção de tal país".
} 
Em decisão de dezembro de 2008, o CONARE indeferiu o pedido de refúgio de Battisti:

[...] não há como enquadrar o pedido nos preceitos de elegibilidade previstos na Lei 9.474/97, eis que não se vislumbra a existência de fundado temor de perseguição pelos motivos ali elencados, assim como não há que se falar em generalizada violação de direitos humanos na Itália.

Da decisão do CONARE, o italiano, com fulcro no art. 29, da Lei ํo. 9.474/97, interpôs recurso ao Ministro da Justiça - na época Tarso Genro. Em janeiro de 2009, o então Ministro da Justiça reconheceu a condição de refugiado a Cesare Battisti, nos termos do art. 1ำ, inc. I, da Lei no. 9.474/97.

Segundo a decisão de Genro:

Não resta a menor dúvida, independentemente da avaliação de que os crimes imputados ao recorrente sejam considerados de caráter político ou não - aliás inaceitáveis, em qualquer hipótese, do ponto de vista do humanismo democrático - de que é fato irrefutável a participação política do Recorrente, o seu envolvimento político insurrecional e a pretensão, sua e de seu grupo, de instituir um poder soberano "fora do ordenamento". [grifos do original].

Por fim, concluiu Genro que não há impedimentos jurídicos para o reconhecimento do caráter de refugiado de Battisti, visto que "em nenhum momento o Estado requerente noticia a condenação do mesmo por crimes impeditivos do reconhecimento da condição de refugiado, estabelecidos no art. $3^{\circ}$, inc. III, da Lei ํo. 9.474/97", ou seja, crime contra a paz, crime de guerra, crime contra a humanidade, crime hediondo, participado de atos terroristas ou tráfico de drogas.

\section{A retomada da Extradição 1.085 - República Italiana}

Reconhecida tal condição de refugiado, o normal seria o arquivamento do pedido de extradição, com base no art. 33 da Lei n. 9474/97, e consequentemente a expedição de alvará de soltura, visto que este prevê: "o reconhecimento da condição de refugiado obstará o seguimento de qualquer pedido de extradição baseado nos fatos que fundamentaram a concessão de refúgio". 
Entretanto, o relator do caso, Ministro Cezar Peluso resolveu retomar o processo de extradição, considerando em seu extenso voto, entre outros temas, três importantes questões que foram também analisadas pelos demais Ministros no plenário: i) o caráter do ato administrativo do Ministro da Justiça, se discricionário ou vinculado; ii) a natureza dos crimes imputados ao extraditando, se políticos ou não; e iii) se o Presidente da República está ou não vinculado à decisão do STF.

\subsection{Análise do ato administrativo do Ministro da Justiça}

A análise do ato administrativo de concessão de refúgio pelo Ministro da Justiça é uma das novidades que traz o caso Battisti (Ext. 1.085), especialmente se considerarmos o que o próprio Ministro Peluso explicitou meses antes na Ext. 1.008:

[...] o fato gerador da concessão de refúgio é impeditivo da concessão de extradição. Não importa que a lei, no caso, considere o caso prejudicado, porque a norma enuncia que o processo não deve prosseguir, pois chegaria ao fim inutilmente por ser um caso de inadmissibilidade superveniente de extradição. ${ }^{10}$

Acrescentou:

Não vejo motivo nenhum de reconhecimento de inconstitucionalidade ao disposto no artigo 33 [...] absolutamente não está em jogo, a meu ver, e com o devido respeito, o princípio da separação de poderes. Assim como nos outros casos em que a lei discipline hipóteses nas quais a competência do Supremo está adstrita à observância de certos requisitos legais, não há aqui interferência nenhuma e cada Poder age dentro de sua esfera de competência. É o caso que a lei disciplina como de inadmissibilidade de extradição. ${ }^{11}$

\footnotetext{
${ }^{10}$ Brasil. Supremo Tribunal Federal (2007). "Extradição 1.008 - República da Colômbia”, Relator: Ministro Gilmar Mendes, Brasília, 17 ago. In Diário de Justiça Eletrônico. Disponível em: <http://www.stf.jus.br/portal/processo/verProcessoAndamento.asp?incidente=2324865>. Acesso em: 31 mar. 2014.

${ }^{11}$ Ibidem.
} 
Q Ministro Peluso entendeu surpreendentemente que, no caso Battisti, o ato do Ministro da Justiça de concessão de refúgio era ilegal e, portanto, o processo extradicional deveria continuar. Cezar Peluso considerou que:

Em suma, a decisão do Senhor Ministro da Justiça não escapa ao controle jurisdicional sobre eventual observância dos requisitos de legalidade, sobretudo à aferição de correspondência entre sua motivação necessária declarada e as fattispecie normativas pertinentes, que é o terreno em que ganha superior relevo a indagação de juridicidade dos motivos, até para averiguar se não terá sido usurpada, na matéria de extradição, competência exclusiva do Supremo Tribunal Federal. ${ }^{12}$

Para o Ministro-relator do processo extradicional, o ato administrativo do Ministro da Justiça invadiu competência do Supremo Tribunal Federal, tornando-se ilegal. Em debate com a Ministra Carmen Lúcia sob a mudança de posicionamento em relação à análise do ato administrativo de concessão de refúgio - a partir da Ext. 1.008 -, o Ministro Peluso confirmou que entende que o ato do Ministro da Justiça é ato vinculado, e não discricionário:

Sendo discricionário, só em casos excepcionais poderia investigar a legalidade; mas, sendo ato vinculado, a primeira coisa que o tribunal tem que examinar, os juízes têm que examinar é se o ato observou, ou não, os requisitos legais de sua existência. Se o juízo ou o tribunal verificar até de ofício que, sendo vinculado, 0 ato não atendeu aos requisitos legais, 0 tribunal tem obrigação de lhe decretar a ilegalidade porque se trata de nulidade absoluta. E as nulidades absolutas independem de arguição são pronunciáveis de ofício por dever do Tribunal. Noutras palavras, o Judiciário tem obrigação de velar pela legalidade estrita dos atos administrativos nas causas que Ihe são sujeitas. ${ }^{13}$

Tal manifestação por parte do Ministro-relator do processo gerou acirrado debate entre alguns Ministros. Especialmente, por parte da Ministra Cármen Lúcia, que entendia que se tratava de um "ato político-administrativo", portanto não vinculado.

\subsection{Crime comum ou crime político?}

\footnotetext{
${ }^{12}$ Brasil. Supremo Tribunal Federal (2009). "Ext. 1.085 - República Italiana”, Relator: Ministro Cezar Peluso, Brasília, 16 dez. In Diário de Justiça Eletrônico. Acesso em: 31 mar. 2014.

Disponível em: http://www.stf.jus.br/portal/processo/verProcessoAndamento.asp?incidente=2514526 .

${ }^{13}$ Ibidem.
} 
O Ministro Peluso examinou de forma mais detida se os crimes imputados ao extraditando seriam crimes comuns ou crimes com conotação política, recordando a situação italiana na época dos crimes e a atual. Isto porque, como se viu, a concessão de refúgio se deu ao abrigo do art. 1ํㅡ, I, da Lei n. 9.474/97, ou seja, "devido a fundados temores de perseguição por motivos de raça, religião, nacionalidade, grupo social ou opiniões políticas".

Para tanto, entendeu o relator, é preciso analisar os termos substantivos da decisão da autoridade administrativa, razão pela qual resumiu os motivos que levaram o Ministro da Justiça Tarso Genro a conceder o refúgio: a) a Itália da época dos acontecimentos teria deixado de ser Estado democrático de direito, utilizando-se de leis de exceção, que reduziram as prerrogativas de defesa dos acusados de subversão e impossibilitaram, especialmente a Battisti, um julgamento justo de acordo com as garantias do devido processo legal; b) o estado italiano se achava sob dominação de um "poder oculto" e que os processos contra o extraditando teriam sido, no fundo, conduzidos por forças políticas subterrâneas que lhe ditaram as sentenças condenatórias; c) que 0 fato de ter sido preso em divisão policial de operações especiais, onde se abrigavam presos políticos, seria evidente a natureza política dos crimes do extraditando; e, d) sua condição política na França, onde de início fora acolhido como militante político de esquerda, a título de asilo informal.

No entendimento do Ministro-relator, seria preciso, então, examinar esses quatro motivos, declarados como fundamentos do ato administrativo vinculado, perante 0 disposto no art. 1ำ I, da Lei federal 9.474/97, para, "no estrito controle de legalidade, ajuizar-se, sendo acaso verdadeiros como fatos, correspondem, ou não, ao suporte fático (fattispecie abstrata) dessa norma vinculante, expressamente invocada pela autoridade como fonte da legitimidade de seu comportamento".

Para ele, se houve mesmo naquele período histórico tal situação política na Itália, "a toda evidência não pode ser considerada atual de algum fundado temor de perseguição futura por motivos políticos". 14

Quanto ao segundo fundamento da decisão, isto é, de que, à época dos acontecimentos, o governo italiano estava infiltrado de "forças políticas eversivas", cujo 'poder oculto' superou e excedeu, em atuações ilegítimas, 'a própria exceção legal',

\footnotetext{
${ }^{14}$ Ibidem.
} 
influindo, de maneira direta ou indireta, nas condenações do extraditando, o Ministrorelator também o rejeita de maneira peremptória, afirmando não se apoiar em nenhum dado da realidade.

A respeito do terceiro fundamento, ou seja, quanto à natureza política dos crimes imputados ao extraditando, o Ministro-relator entendeu que "a autoridade administrativa carece de toda competência na matéria".

$\mathrm{Na}$ falta, de uma definição doutrinária, o Ministro-relator defendeu que a competência para dizer o que é ou não é crime político é do próprio STF, para tanto, cita dois dispositivos legais - 0 art. 102, I, g, da Constituição Federal, in verbis:

Compete ao Supremo Tribunal Federal, precipuamente, a guarda da Constituição, cabendo-Ihe: I - processar e julgar, originariamente: [...] g) a extradição solicitada por Estado estrangeiro", e o art. 77, §20, da Lei 6.815/80, segundo o qual "Caberá, exclusivamente, ao Supremo Tribunal Federal, a apreciação do caráter da infração.

O quarto e último fundamento - a condição política de Battisti na França - foi qualificado pelo Ministro-relator como "impertinente às inteiras", entendendo que os acontecimentos ocorridos na França são "todo irrelevantes as respectivas considerações da autoridade administrativa para o desate da causa".

Retomando o debate sobre se os crimes imputados ao extraditando podem ser considerados políticos ou não, o Ministro-relator defendeu que os quatro homicídios, além de não apresentarem nenhuma conotação política, "entram com folga na classe de crimes comuns graves, qualificados de hediondos nos termos do art. 1ํ, da Lei n. 8.072/90”, o que impediria a concessão de refúgio, nos termos do art. $3^{\circ}$, III, da Lei n. 9.474/97.

\subsection{Obrigatoriedade ou discricionariedade do Presidente em (não) entregar Battisti?}

O último ponto a ser examinado é sobre a obrigatoriedade ou não do Presidente da República, acolhido o pedido de extradição pelo Supremo Tribunal Federal, efetivar a entrega do extraditando ao Estado requerente, no caso a Itália. 
É uma questão muito pertinente e que nunca havia ficado muito clara, nem na doutrina nem nas decisões do STF, mesmo porque a hipótese em si não parecia muito provável, ou seja, não há precedentes de que, concedida a extradição, o Presidente da República não haver entregado o reclamado. No plano dogmático, o tema era relativamente dividido, alguns optando pela obrigatoriedade do Presidente da República e outros pela discricionariedade.

A posição do Ministro-relator foi de que o Presidente da República é obrigado a entregar o extraditando, no caso do plenário do STF ter acolhido o pedido extradicional. No entendimento do Ministro, somente, a título excepcional, o art. 89, caput e parágrafo único, da Lei n. 6.815/80, prevê uma única hipótese em que se possa adiar a entrega do extraditando, "mas nunca deixar de efetivá-la".

Ressaltando, também, o que prevê o art. 1ํ do Tratado de Extradição Brasil-Itália, concluiu o Ministro que:

De modo que, em resumo, preenchidos todos os requisitos que autorizam a extradição e, por conseguinte, não caindo o pedido em nenhuma das hipóteses de recusa ou de recusa facultativa, está a Parte requerida obrigada a entregar à outra as pessoas procuradas que se encontrem em seu território. Este é princípio capital da teoria e prática dos tratados, pois não tem nexo nem senso conceber que sejam celebrados para não serem cumpridos por nenhum dos Estados contraentes! $!^{15}$

Por tudo exposto, o Ministro Peluso deferiu o pedido de extradição de Cesare Battisti. Contrário nesse ponto, por exemplo, o Ministro Joaquim Barbosa que lembrou a Ext. 1.114, decisão recente e por unanimidade:

O Supremo Tribunal Federal limita-se a analisar a legalidade e a procedência do pedido de extradição (Regimento Interno do Supremo Tribunal Federal, art. 207; Constituição da República, art. 102, inciso I, alínea g; e Lei n. 6.815/80, art. 83): indeferido o pedido, deixa-se de constituir o título jurídico sem o qual o Presidente da República não pode efetivar a extradição; se deferida, a entrega do súdito ao Estado requerente fica a critério discricionário do Presidente da República. ${ }^{16}$

\footnotetext{
${ }^{15}$ Brasil. Supremo Tribunal Federal (2009). "Ext. 1.085 - República Italiana”, Relator: Ministro Cezar Peluso, Brasília, 16 dez. In Diário de Justiça Eletrônico. Disponível em: $<$ http://www.stf.jus.br/portal/processo/verProcessoAndamento.asp?incidente=2514526>. Acesso em: 31 mar. 2014.

${ }^{16}$ Brasil. Supremo Tribunal Federal (2008). "Ext. 1.114 - República do Chile”, Relatora: Ministra Cármen Lúcia, Brasília, 25 mar. In Diário de Justiça Eletrônico. Disponível em:
} 
Quanto ao fato de a lei brasileira ser posterior aos fatos ocorridos, o Ministrorelator foi taxativo ao afirmar que "a gravidade, enquanto impeditiva da concessão de refúgio, é sempre objeto de juízo posterior ao fato criminoso, quer exista, quer não exista lei que a proclame!". 17

A jurisprudência do Supremo Tribunal Federal divide os crimes políticos em puramente políticos e complexos, também chamados de relativos ou mistos, que seriam crimes comuns contaminados por motivação política, de modo que, nos casos em que prepondere o caráter político do delito complexo em relação ao crime comum, o primeiro há de prevalecer.

Para Peluso, de maneira objetiva: "toca a esta Corte sopesar, caso a caso, o contexto fático, histórico, político e social em que tenha sido praticada a conduta delituosa imputada ao extraditando, para daí o fato de caráter preponderante no crime complexo". ${ }^{18}$

\section{A decisão de Lula em manter Battisti no Brasil}

O acórdão da Ext. 1.085 somente foi publicado seis meses depois, ou seja, em abril de 2010, mas o Presidente Lula deixou para o último dia de seu mandato o ônus do desgaste político de manter o italiano Cesare Battisti no Brasil, acolhendo parecer da Advocacia Geral da União (AGU), assinado pelo consultor da União, Arnaldo Sampaio de Moraes Godoy:

Conclui-se que há ponderáveis razões para se supor que o extraditando possa ser submetido a agravamento de sua situação pessoal. E que, se plausível a premissa, deve-se aplicar o tratado, no sentido de se negar a extradição, insista-se, por força de disposição do próprio tratado, que confere discricionariedade, ao Presidente da República, nos termos do já referido tratado. ${ }^{19}$

\footnotetext{
<http://www.stf.jus.br/portal/processo/verProcessoAndamento.asp?incidente=2592024>. Acesso em: 31 mar. 2014.

${ }^{17}$ Brasil. Supremo Tribunal Federal (2009). ‘Ext. 1.085 - República Italiana”, Relator: Ministro Cezar Peluso, Brasília, 16 dez. In Diário de Justiça Eletrônico. Disponível em: <http://www.stf.jus.br/portal/processo/verProcessoAndamento.asp?incidente=2514526>. Acesso em: 31 mar. 2014.

${ }^{18}$ Ibidem.

${ }^{19}$ Godoy, Arnaldo Sampaio de Moraes (2010). "Extradição. República Italiana. Julgamento do Supremo Tribunal Federal. Requisitos de caráter puramente subjetivos do Presidente da República". In Revista da $A G U$, n. 26, out./dez., p. 8.
} 
O consultor da União encontrou o fundamento da não entrega no próprio Tratado de Extradição Brasil-Itália e no art. $3^{\circ}$ deste instrumento internacional, como queria o Ministro Eros Grau:

Art. 3․ 1. A extradição não será concedida: [...] f) se a parte requerida tiver ponderáveis razões para supor que a pessoa reclamada será submetida a atos de perseguição e discriminação por motivo de raça, religião, sexo, nacionalidade, língua, opinião política, condição social ou pessoal; ou que sua situação possa ser agravada por um dos elementos antes mencionados.

Para explicitar esse fundamento legal, sustentou que:

A condição pessoal do extraditando, agitador político que teria agido nos em [sic] anos difíceis da história italiana, ainda que condenado por crime comum, poderia, salvo engano, provocar reação que poderia, em tese, provocar no extraditando, algum tipo de agravamento de sua situação pessoal. Há ponderáveis razões para se supor que o extraditando poderia, em princípio, sofrer alguma forma de agravamento de sua situação. ${ }^{20}$

Por fim, o parecer ressaltou que:

Ao STF não cabe a apreciação do mérito do pedido. Apenas, e tão somente autoriza-se ao Presidente da República a efetivar a extradição. Isto é, na hipótese do STF comprovar que o pedido de extradição substancialize os requisitos indicativos da garantia dos direitos fundamentais do extraditando.

Consequentemente, infere-se, a extradição decorre de procedimento misto para deferimento. O STF verifica os requisitos de legalidade, bem como de procedência do pedido. Em seguida, o Presidente da República decide, com margem de discricionariedade, tal como o consignado nos tratados que assinamos. ${ }^{21}$

A decisão do Presidente da República saiu na edição extra do Diário Oficial da União de 31 de dezembro de 2010:

Processo no 08000.003071/2007-51. Parecer no AGU/AG-17/2010, adotado pelo Advogado-Geral da União Substituto, referente ao pedido de

\footnotetext{
${ }^{20}$ Ibidem, p. 77.

${ }^{21}$ Ibidem, p. 79.
} 
Extradição no 1.085, requerido pela República Italiana. Em face dos fundamentos, aprovo o Parecer e nego a extradição. ${ }^{22}$

Com a decisão do Presidente da República de não entregar Battisti, nos termos do Tratado de Extradição, a defesa de Battisti, por meio de seu advogado, Luis Roberto Barroso, peticionou no dia 4 de janeiro de 2011, requerendo: a) que o STF expedisse, de imediato, alvará de soltura, ou, b) em via alternativa, que declarasse esgotada sua jurisdição, tocando aos órgãos do Poder Executivo a responsabilidade pelo cumprimento da decisão presidencial.

O Ministro Cezar Peluso, então presidente do STF, recebeu a solicitação, despachando-a, e, quanto à discricionariedade do Chefe do Executivo, assinalou:

[...] De nenhum relevo ao propósito a opinião isolada que, integrando voto, pudesse sugerir liberdade absoluta do Exmo. Sr. Presidente da República em tema de entrega, ou não, do extraditando, diante do inequívoco teor do dispositivo do acórdão que, expressis verbis, subordinou a legitimidade do ato de S. Ex", uma vez decretada a extradição, à observância dos "termos do Tratado celebrado com o Estado requerente, quanto à entrega do extraditando". Tal enunciado seria escusável, se não guardasse consequência prática no mundo jurídico. ${ }^{23}$

\section{O final: análise da petição avulsa na Extradição 1.085 e da Reclamação 11.243}

Com o indeferimento do pedido de liberdade de Battisti, a decisão final sobre se a determinação do presidente Lula era válida - e consequentemente os limites da decisão do STF no processo de extradição - foram decididos pelo plenário do STF, em maio de 2011, com uma importante e decisiva mudança na sua composição, já que o Ministro Eros Grau havia se aposentado e substituído por Luiz Fux.

A análise conjunta da petição avulsa da defesa no bojo da Ext. 1.085 - pedido de relaxamento da prisão de Battisti com base na decisão presidencial - e da RCL 11.243 contra a decisão do Presidente da República que negou o pedido de extradição - ficou com a relatoria do Ministro Gilmar Mendes.

\footnotetext{
22 Brasil (2010). Diário Oficial da União, 31 dez.

${ }^{23}$ Brasil. Supremo Tribunal Federal (2011). "Andamento do Processo Extradição 1085 República Italiana". Brasília, 6 jan. In Diário de Justiça Eletrônico. Disponível em: http://www.stf.jus.br/portal/processo/verProcessoTexto.asp?id=2921601\&tipoApp=RTF. Acesso em: 31 mar. 2014.
} 
O relator dividiu o processo de extradição em três fases: a primeira, de natureza administrativa, caracterizada pela apresentação pela via diplomática do governo estrangeiro ao Governo brasileiro; a segunda, eminentemente jurisdicional e processada perante o STF; e uma terceira fase, que o Ministro chama de "natureza jurídica da intervenção do Presidente da República após a concessão, pelo STF, da extradição". O próprio Ministro coloca um questionamento: essa terceira fase seria "de execução desse acórdão ou a decisão do Presidente é autônoma em relação ao processo de extradição no STF?". 24

O Ministro Gilmar Mendes, antes de examinar essa terceira fase do processo de extradição, afirmou que:

O cumprimento dessa precípua tarefa por parte da Corte não tem o condão de interferir negativamente nas atividades dos Poderes Executivo e Legislativo. Não há "judicialização da política" quando as questões controvertidas invocam diretamente a aplicação das normas constitucionais. Essa tem sido a orientação fixada pelo Supremo Tribunal Federal, desde os primórdios da República. ${ }^{25}$ [grifos do original]

O Ministro entende que "a competência do STF não se encerra com a decisão que põe fim à segunda fase", visto que "o extraditando permanece preso sob a custódia do Tribunal, e apenas a decisão do próprio Tribunal pode determinar a soltura". Por isso, nessa terceira fase, o "STF continua a exercer sua precípua função de, no processo de extradição, resguardar a incolumidade do ordenamento constitucional e dos direitos fundamentais do extraditando". ${ }^{26}$

Mais adiante, o Ministro Gilmar Mendes rejeitou a afirmação de que a decisão do STF no processo de extradição é meramente autorizativa e, consequentemente, poderia o Executivo apreciar a conveniência quanto ao cumprimento da decisão. Afirma em seu voto: "a atuação do Presidente da República na terceira fase da extradição, portanto, é essencialmente vinculada aos parâmetros estabelecidos na decisão do STF que autoriza a extradição".

\footnotetext{
${ }^{24}$ Brasil. Supremo Tribunal Federal (2011). "Rcl 11243/República Italiana”, Relator Originário: Ministro Gilmar Mendes, redação para o acórdão Ministro Luiz Fux, Brasília, 8 jun. In Diário de Justiça Eletrônico. Disponível em: $<\mathrm{http}: / / \mathrm{www}$. stf.jus.br/portal/processo/verProcessoAndamento.asp?incidente $=4024096>$. Acesso em: 31 mar. 2014.

25 Ibidem.

26 Ibidem.
} 
Dessa forma, o Ministro relator passa a examinar se a decisão presidencial respeitou a discricionariedade dada ao Presidente da República, reconhecida por maioria na Ext. 1.085, quanto à execução da decisão que deferiu a extradição, isto é, delimitada pelos termos do tratado de Brasil-Itália.

Portanto, na parte final do voto, o Ministro Gilmar Mendes debruça-se sobre a interpretação da letra "f" do número 1 do art. 3ํ do Tratado de Extradição celebrado entre o Brasil e a Itália:

\begin{abstract}
Parece evidente que a verificação da existência de razões ponderáveis, ainda que sugira uma margem de apreciação por parte do intérprete, deve necessariamente ser interpretada de acordo com o contexto no qual a situação encontra-se inserida. Como toda interpretação que se faz em torno dos chamados conceitos jurídicos indeterminados, essa expressão deve ser objeto de uma hermenêutica que leve em conta todas as circunstâncias fáticas e jurídicas da situação. [...]

Não se trata, assim, de uma simples avaliação subjetiva, que possa ser feita sem critérios. [...] o agente público, ao apreciar a existência ou não dessas razões ponderáveis, em determinada hipótese, também está diretamente vinculado à realidade fática da situação a que corresponde.

Com isso, a avaliação sobre a existência ou não de razões ponderáveis passa a ter, no contexto da realidade internacional contemporânea, estreita ligação com o Estado Democrático de Direito e com a garantia de que direitos fundamentais do extraditando serão preservados pelo país requerente, a partir de elementos concretamente aferíveis. Caso contrário, haveria razões ponderáveis e aceitáveis de que o pedido de extradição fosse recusado. ${ }^{27}$
\end{abstract}

No entendimento do Ministro, a decisão de recusa da extradição "não trouxe elemento diverso a ser considerado pela Corte, em nada inovando com relação ao debate travado anteriormente, de forma que subsistem as razões expendidas pelo STF". Assim, votou no sentido de "desconstituir o ato reclamado e determinar a imediata entrega do extraditando ao país requerente". ${ }^{28}$

Todavia, o Ministro Luiz Fux, primeiro a votar depois do Ministro relator, tomou posição contrária, liderando a dissidência, que consagraria a maioria. Para ele, o caso em tela não se limita ao destino de Cesare Battisti, mas à soberania nacional frente à irresignação da República Italiana.

Sobre a questão central do debate, se uma vez deferida a extradição pelo STF estaria o Presidente da República obrigado a entregar o extraditando, o Ministro Luiz Fux

\footnotetext{
${ }^{27}$ Ibidem.

28 Ibidem.
} 
lembra que a indagação já fora enfrentada neste mesmo processo de extradição por meio de Questão de Ordem, em que se entendeu que "a decisão de deferimento da extradição não vincula o Presidente da República", citando inclusive o Ministro Eros Grau que entendeu que "não se trata [...] de ato discricionário, porém, de ato regrado, ato vinculado ao que dispõe o tratado". 29

Afirmou o Ministro Luiz Fux:

Malgrado tenha este Supremo Tribunal anulado a decisão do Ministro da Justiça que concedeu refúgio político ao extraditando, não pode, agora, substituir-se ao Chefe de Estado e determinar a remessa de Cesare Battisti às autoridades italianas. Uma decisão com comando semelhante, exigindo que o Presidente da República proceda a extradição, seria tão aberrante e tão contrária aos cânones constitucionais quanto um imaginário acórdão que determinasse a secessão de um Estado-membro. [...] Assim, ao se considerar os princípios da separação dos poderes e da soberania, bem como as previsões constitucionais de competência privativa do Presidente da República (especialmente o tantas vezes citado art. 84, inciso VII), o ato presidencial objeto da presente Reclamação é constitucional e legal. ${ }^{30}$

Na ocasião, o Ministro remeteu-se ao tema da judicialização da política, ao afirmar que "o Judiciário não foi projetado constitucionalmente para tomar decisões políticas na esfera internacional, cabendo tal papel ao Presidente da República, eleito democraticamente e com legitimidade para defender os interesses do Estado exterior". ${ }^{1}$

Com esse voto e sendo designado como relator para o acórdão, o Ministro Luiz Fux rejeitou a Reclamação da República Italiana, consequentemente mantendo-se a decisão da Presidência da República e, por fim, procedendo-se à imediata liberação de Cesare Battisti. Vencidos os Ministros Gilmar Mendes, relator, Ellen Gracie e Cezar Peluso, o acórdão foi assim ementado:

Capacidade institucional atribuída ao Chefe de Estado para proceder à valoração da cláusula permissiva do diploma internacional. Vedação à intervenção do Judiciário na política externa brasileira. Artigo 84, VII, da Constituição da República. ${ }^{32}$

\section{Conclusão}

\footnotetext{
29 Ibidem.

${ }^{30}$ Ibidem.

31 Ibidem.

32 Ibidem.
} 
Embora seja possível concluir que o STF adotou, na hipótese, o posicionamento de que seu controle sobre o processo de extradição seria meramente de legalidade, os debates acirrados e as contradições existentes dentro dos votos e análises da Corte indicam que o limite à ingerência do tribunal constitucional sobre o rito extradicional ainda é questão indefinida.

Mais ainda, depreende-se que, sob a égide do controle de legalidade, o Supremo Tribunal Federal justifica a eventual vinculação do Presidente da República às suas decisões, impedindo que a entrega do extraditando vá de encontro ao ordenamento jurídico brasileiro.

No entanto, a discussão formal pode ocultar o verdadeiro cerne da questão - os embates políticos entre os Poderes Executivo e Judiciário e a possibilidade de, por meio de uma roupagem jurídica, submeterem-se questões atinentes à soberania do país e à discricionariedade sobre sua política externa ao crivo da Corte Suprema brasileira.

\section{Referências}

Brasil (2010). Diário Oficial da União, 31 dez.

Brasil. Supremo Tribunal Federal (2007). "Extradição 1.008 - República da Colômbia", Relator: Ministro Gilmar Mendes, Brasília, 17 ago. In Diário de Justiça Eletrônico. Disponível em: http://www.stf.jus.br/portal/processo/verProcessoAndamento.asp?incidente=2324865>. Acesso em: 31 mar. 2014.

(2008). "Ext. 1.114 - República do Chile", Relatora: Ministra Cármen Lúcia, Brasília, 25 mar. In Diário de Justiça Eletrônico. Disponível em: <http://www.stf.jus.br/portal/processo/verProcessoAndamento.asp?incidente=2592024>. Acesso em: 31 mar. 2014.

(2009). "Ext. 1.085 - República Italiana”, Relator: Ministro Cezar Peluso, Brasília, 16 dez. In Diário de Justiça Eletrônico. Disponível em: <http://www.stf.jus.br/portal/processo/verProcessoAndamento.asp? incidente=2514526>. Acesso em: 31 mar. 2014. 
\begin{tabular}{ccccc} 
& (2011). "Andamento do Processo Extradição 1085 República Italiana". Brasília, \\
\hline jan. In Diário de Justiça Eletrônico. Disponível em:
\end{tabular} http://www.stf.jus.br/portal/processo/verProcessoTexto.asp?id=2921601\&tipoApp=RTF. Acesso em: 31 mar. 2014.

(2011). "Rcl 11243/República Italiana", Relator Originário: Ministro Gilmar Mendes, redação para o acórdão Ministro Luiz Fux. Brasília, 8 jun. In

Diário de Justiça Eletrônico. Disponível em: <http://www.stf.jus.br/portal/processo/verProcessoAndamento.asp?incidente=4024096>. Acesso em: 31 mar. 2014.

Dworkin, Ronald (2007). Levando os direitos a sério. 2 ed, São Paulo: Martins Fontes.

Godoy, Arnaldo Sampaio de Moraes (2010). "Extradição. República Italiana. Julgamento do Supremo Tribunal Federal. Requisitos de caráter puramente subjetivos do Presidente da República". In Revista da AGU, n. 26, p. 7-81, out./dez.

Hirschl, Ran (2008). "The Judicialization of Mega-Politics and the Rise of Political Courts". In The Annual Review of Political Science, v. 11, n. 1, p. 93-118.

Mello, Celso Antônio Bandeira de (2009). Curso de Direito Administrativo. 26. ed., São Paulo: Malheiros.

Sarmento, Marcelo (2009). "Neoconstitucionalismo no Brasil: riscos e possibilidades". In Novelino, Marcelo (Org.) (2009). Leituras complementares de Direito Constitucional. Teoria da Constituição. Salvador: Jus Podivm, p. 31-68.

Villaméa, Luiza (2009). "Cesare Battisti: 'Por que tudo isso comigo?'”. In Isto é, São Paulo, v. 2047, 4 fev.

Recebido para publicação em 31 de março de 2014.

Aprovado para publicação em 09 de junho de 2014. 